ABDI: Jurnal Pengabdian dan Pemberdayaan Masyarakat ISSN: 2656-369X (Print), 2684-8570 (Online)

Volume 2 No. 2, Desember 2020

http://abdi.ppj.unp.ac.id/index.php/abdi

Email: abdi@ppj.unp.ac.id

DOI: https://doi.org/10.24036/abdi.v2i2.59

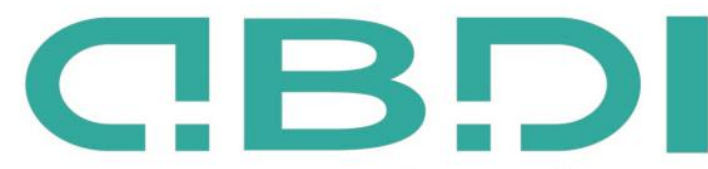

ABDI: JURNAL PENGABDIAN DAN PEMBERDAYAAN MASYARAKAT

\title{
Pengemasan (Packaging) Rakik Bada Lado Hijau Upaya Peningkatan Pemasaran dan Pelestarian Kuliner Minangkabau
}

\author{
Erda Fitriani $^{1}$, Siti Fatimah ${ }^{2}$, Desy Mardhiah ${ }^{3}$, Selinaswati Selinaswati ${ }^{4}$, Muhammad Hidayat ${ }^{5}$, \\ Lia Amelia ${ }^{6}$
}

1,3,4,5,6 Jurusan Sosiologi, Universitas Negeri Padang

2 Jurusan Sejarah, Universitas Negeri Padang

E-mail: fitriani_cim@fis.unp.ac.id, siti fatimahunp@ fis.unp.ac.id

\begin{abstract}
Abstrak
Rakik Bada merupakan salah satu kuliner Minangkabau yang dapat dikembangkan sebagai usaha rumah tangga. Permasalahan yang ditemui di Nagari Sungai Pinang Pesisir Selatan, usaha rakik bada sudah ada akan tetapi belum dikemas dengan baik dengan mencantumkan label, dan tangal produksi serta tanggal kadarluasa dari produk. Pencantuman tanggal kadarluasa sangat penting bagi makanan dan minuman yang memiliki waktu kualitas terbaik yang sangat singkat. Oleh karena itu untuk peningkatan nilai ekonomis dari kuliner rakik bada perlu dilakukan pendampingan, dalam hal pelatihan pengemasan atau packaging. Kelompok sasaran adalah ibuibu PKK Nagari Sungai Pinang. Pelatihan dilaksanakan mulai dari membuat produk rakik bada lado hijjau dan pemberian pengetahuan pentingnya pengkemasan dan pemberian label pada produk. Evaluasi hasil dilihat dari penilaian karya mandiri dan mencermati partisipasi dari para peserta. Hasil evaluasi menunjukkan bahwa pelatihan dapat memberikan pengetahuan kepada mitra mengenai alternatif kemasan yang dapat dipilih untuk menampilkan produk yang lebih baik di pasaran dan pemberian label dapat membantu memberikan informasi kepada konsumen.

Kata kunci: Pengemasan, Pemasaran, Pelestarian, Kuliner Minangkabau

\section{Abstract}

Rakik Bada is one of the Minangkabau culinary delights that can be developed as a household business. The problem encountered in Nagari Sungai Pinang Pesisir Selatan is that the rakik bada business already exists but has not been packaged properly by including the label, the production date and the expiration date of the product. Inclusion of the expiration date is very important for foods and drinks that have the best quality time is very short. Therefore, to increase the economic value of Rakik Bada culinary, assistance is needed, in terms of packaging training. The target group is PKK Nagari Sungai Pinang women. The training was carried out starting from making rakik bada green pepper products and providing knowledge on the importance of packaging and labeling products. The evaluation of the results is seen from the independent work assessment and looks at the participation of the participants. The results of the evaluation show that the training can provide knowledge to partners about packaging alternatives that can be chosen to better display products on the market and labeling can help inform consumers.
\end{abstract}

Key words: Packaging, Marketing, Preservation, Minangkabau culinary.

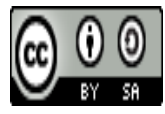

Received: 20 Oktober $2020 \quad$ Revised: 10 November $2020 \quad$ Available Online: 11 November 2020

\section{ABDI: Jurnal Pengabdian dan Pemberdayaan Masyarakat Vol. 2 No. 2




\section{Pendahuluan}

Salah satu aspek penting dalam bisnis makanan adalah pengkemasan (packaging) produk dan pemberian label makanan. Fungsi kemasan tidak lagi sebagai pelindung produk dalam proses transportasi, penyimpanan dan penjualan produk akan tetapi juga alat sebagai pendorong dalam meningkatkan penjualan (Maryama et al., 2018);(Hantoro \& Soewito, 2018). Dengan adanya kemasan yang baik, kualitas makanan dapat terjaga dengan baik dan dapat meningkatkan daya jual dengan menampilkan bentuk kemasan yang menarik. Selain produk dikemas dengan baik, juga sebaiknya diberi label. Kewajiban untuk mencantumkan informasi di kemasan produk telah diatur dalam UndangUndang No 18 Tahun 2018 tentang pangan.

Berdasarkan regulasi yang mengatur label tersebut, maka menjadi kewajiban bagi pelaku usaha untuk mencantumkan label terhadap produk makanan kemasan agar memberikan rasa aman bagi konsumen. Selain mencantumkan label, pelaku usaha juga wajib mencantumkan informasi yang lengkap terhadap label makanan kemasan sebagaimana diatur dalam pasal 97 ayat (3) Undang-Undang No 18 tahun 2012, yang menyatakan pencantuman label di dalam dan/ atau pada kemasan yang ditulis atau dicetak dengan menggunakan bahasa Indonesia (Pratiwi, 2019).

Makanan tradisional dapat dilestarikan dengan mengembangkan wirausaha berbasis kuliner khas sukubangsa. Minangkabau memiliki banyak jenis kuliner yang populer, terutama rendang yang sudah terkenal di bumi nusantara bahkan dunia (Fajarsari, 2017). Salah satu kuliner Minangkabau yang dapat menjadi wirausaha adalah rakik bada. Rakik bada adalah sejenis makanan ringan jenis kerupuk yang banyak terdapat di nusantara, namun rakik ini memiliki citarasa yang khas, pedas dan di atas rakik ini (topping) diberi ikan kering yang disebut bada (teri) atau lainnya seperti ikan maco, udang, dan ebi. Selain daripada itu, mengembangkan makanan rakik juga dalam rangka mengembangkan potensi desa yang berada di kawasan pesisir pantai, dengan memanfaatkan ikan yang didapat oleh nelayan (Fitriani, 2017).

Nagari Sungai Pinang terletak di daerah kabupaten Pesisir Selatan Sumatera barat. Wilayah ini pada tahun 2018 termasuk desa tertinggal dan juga terisolasi. Salah satu penyebab terisolasi masyarakat yaitu karena kurangnya sarana transportasi, untuk mencapai kawasan nagari hanya dapat dicapai dengan berjalan kaki atau dengan menggunakan perahu boat. Pada tahun 2019 kawasan ini telah dapat menikmati jalan yang beraspal dan tidak lagi terisolasi karena pemerintah telah membangun jalan dan mengembangkan kawasan pariwisata terpadu Mandeh. Masyarakat pada umumnya hidup sebagai petani dan nelayan .

Masyarakat Nagari Sungai Pinang sudah pernah mendapatkan pelatihan pembuatan rakik bada yang difasilitasi oleh pendamping masyarakat dari Walhi pada tahun 2016. Sudah ada beberapa orang warga yang menjadikan rakik sebagai wirausaha. Hanya saja rakik yang dijual belum diberi kemasan yang memadai dan juga belum ada labelnya. Dengan demikian, dipandang urgen untuk memberikan pelatihan pengkemasan dan label makanan rakik bada bagai warga Nagari Sungai Pinang. Apalagi pada saat sekarang ini Nagari Sungai Pinang termasuk Kawasan Pariwisata Terpadu Mandeh. Masyarakat diharapkan terlibat aktif dalam mengembangkan potensi daerah mereka, sehingga mereka diharapkan dapat menjadi subjek dan bukan hanya "penonton" dalam pembangunan pariwisata Mandeh.

Kelompok sasaran atau mitra dalam kegiatan pengabdian masyarakat ini adalah ibu-ibu PKK Nagari Sungai Pinang. Alasan dipilihnya ibu-ibu PKK yaitu untuk mengembangkan wirausaha mandiri nagari, dan peningkatan inkam rumah tangga. Selain itu, nagari ini merupakan daerah pendampingan nagari binaan yang sedang dilakukan oleh tim pengabdian.

Berdasarkan analisa situasi maka permasalahan perioritas mitra adalah bagaimana pembuatan kemasan dan pemberian label untuk makan rakik bada? Walaupun sudah ada bungkus rakik dari plastik, akan tetapi belum terlihat menarik dan tidak mencantumkan label makanan. Tujuan dari pengabdian masyarakat adalah (1) memberikan pengetahuan kepada ibu-ibu PKK tentang pentingnya kemasan makanan dan label; (2) pembuatan produk rakik bada lado hijau; (3) pembuatan kemasan dan pemasangan label. 


\section{Metode Pelaksanaan}

Metode yang dilakukan dalam pengabdian masyarakat ini adalah presentasi, demonstrasi dan praktek secara individu dan kelompok. (1) Metode Presentasi, digunakan untuk menyampaikan beberapa hal yang berkaitan dengan manfaat, fungsi, bahan, alat, yang digunakan untuk membuat rakik bada lado hijau, dan pengkemasan serta label kemasan. (2) Metode Demonstrasi, metode ini digunakan untuk menunjukkan bagaimana cara membuat rakik bada lado hijau yang garing, dan cara pengkemasan. (3) Metode Praktek, metode ini digunakan untuk melatih ibu-ibu PKK dalam membuat kemasan rakik bada dan supaya memiliki pengalaman langsung tentang cara membuat dan memasang label kemasan. (4) evaluasi, metode evaluasi yang dilakukan selama kegiatan berlangsung, evaluasi dapat dilihat dari keaktifan dan keantusiasan para peserta dalam mengikuti program, dan kecakapan dalam melaksankan kegiatan.

Langkah-langkah pelaksanaan kegiatan yang dilakukan yaitu: (1) tim pelaksana mendikusikan dengan ketua PKK dan anggota untuk membahas merek produk; (2) tim pelaksana menyampaikan manfaat dan pentingnya fungsi kemasan kepada peserta; (3) tim pelaksana dan PKK mencetak merek; (4) tim pelaksana mempersiapkan alat dan bahan; dan (5) tim pelaksana mendemostrasikan pembuatan produk dan pengkemasan.

\section{Hasil dan pembahasan}

\subsection{Tahapan Sosialisasi dan diskusi penentuan merk (brand)}

Kegiatan yang pertama kali dilakukan oleh tim pengabdian adalah mendiskusikan dan mengadvokasi pihak pengurus PKK khususnya ketua PKK, supaya memahami pentingnya kemasan dan pemberian label produk makanan. Kegiatan dilakukan di rumah ketua PKK. Namun setelah didiskusikan hal yang harus kami dampingi terlebih dahulu adalah penentuan merk produk ( rand) dari produk yang dalam perencanaanya merek tersebut bisa menjadi merek untuk produk lainnya dari hasil produksi PKK Nagari Sungai Pinang. Pada hari Minggu, tanggal 4 Agustus 2019 dikumpulkan anggota PKK untuk menentukan merek produk dari PKK dan diberikan sosialisasi arti penting dari merek, kemasan dan label dari produk makanan. Pada tanggal 4 September 2019 telah ada beberapa nama dari produk PKK adalah Pesona Sungai Pinang (saran dari ibu ketua PKK); SP-PKM (Sungai PinangPariwisata Kawasan Mandeh) (saran dari ibu Siti Fatimah); SPM (Sungai Pinang Mandiri) dan PSPM (Pariwisata Sungai Pinang Mandiri). Selanjutnya dengan berbagai pertimbangan disepakati bahwa merek produk PKK adalah PSPM (Pariwisata Sungai Pinang Mandiri). Selanjutnya diskusi mengenai desain merek dilakukan melalui via whatsapp dengan pengurus PKK, yang membuat desain adalah tim pengabdian masyarakat dengan mempertimbangkan potensi sumber daya alam dan budaya yang ada di Nagari Sungai Pinang. Pada tanggal 18 September desain merk sudah selesai dicetak.

Dalam pelaksanaan kegiatan sosialisasi mengenai pentingnya pengkemasan dan label produk ini tidak ditemukan kendala oleh karena masyarakat sasaran sangat antusias dalam mengikuti kegiatan ini dan partisipasinya cukup baik. Sehingga kegiatan sosialisasi yang direncanakan dapat berjalan dengan lancar. Dalam berdiskusi menentukan merek produk PKK, para peserta juga antusias dengan ikut terlibat aktif memberikan ide berkaitan dengan nama merek produk.

\section{b. Pelaksanaan kegiatan pelatihan pembuatan rakik bada lado hijau dan pengkemasan}

Pelatihan pembuatan rakik bada lado hijau dan pengkemasan dilaksanakan pada hari Minggu, tanggal 21 September 2019. Tempat pelaksanaan kegiatan yaitu ruang PKK Nagari Sungai Pinang. Instruktur kegiatan yaitu Hendra Fauzi, S.Pd.

Bahan-bahan yang diperlukan sudah disiapkan, bahan utama yaitu bada, tepung, telur, bumbu seperti cabe hijau, bawang, ketumbar, jahe, kunyit, daun jeruk, kemiri dan air. Bahan kemasan yang utama adalah label yang sudah dicetak, dan plastik. Cara membuat rakik bada lado hijau yaitu: (1) Haluskan ketumbar, cabe, bawang merah, bawang putih, jahe, kunyit, kemiri. Campurkan bersama tepung beras, tapioka, telur, daun jeruk, garam, kapur sirih penyedap rasa (royco). Tambahkan air 
sedikit demi sedikit, jangan sampai adonan encer kemudian sesuaikan rasa. (2) Panaskan minyak goreng dengan api sedang. (3) Setelah minyak panas, panaskan cetakan, setelah cetakan panas tuangkan adonan kedalam cetakan dan taburkan ikan maco/bada pada adonan. Kemudian goreng kedalam minyak sampai adonan tidak lengket lagi dicetakan. (4) Goreng hingga rakik sampai kuning keemasan dan crispy. Kemudian angkat dan tiriskan rakik maco. Rakik maco/bada siap dihidangkan.

Pelaksanaan diawali dengan demonstrasi yang dilakukan oleh instruktur selanjutnya diikuti oleh para peserta. Para peserta sangat antusias dalam melaksanakan kegiatan ini dan kegiatan dapat berjalan dengan lancar. Pada gambar 1 terlihat suasana pelatihan pembuatan rakik bada lado hijau yang diikuti oleh para peserta dengan antusias.

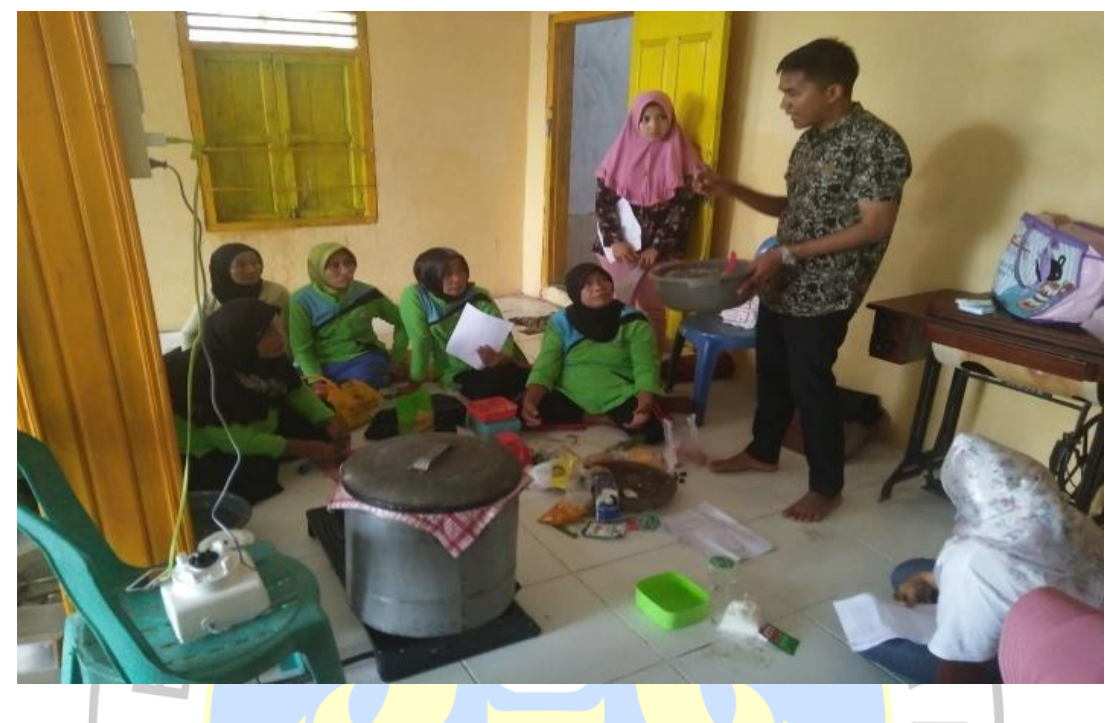

\section{Gambar 1. Instrukstur memberikan pengarahan tentang pembuatan rakik bada lado hijau}

Produk akan memiliki ketahanan yang baik dan cukup lama jika dikemas dengan baik, pada gambar 2 terlihat para peserta yang sedang memasukkan produk ke dalam kemasan, dan pada gambar 3 fapat dilihat produk rakik bada yang sudah diberi label.

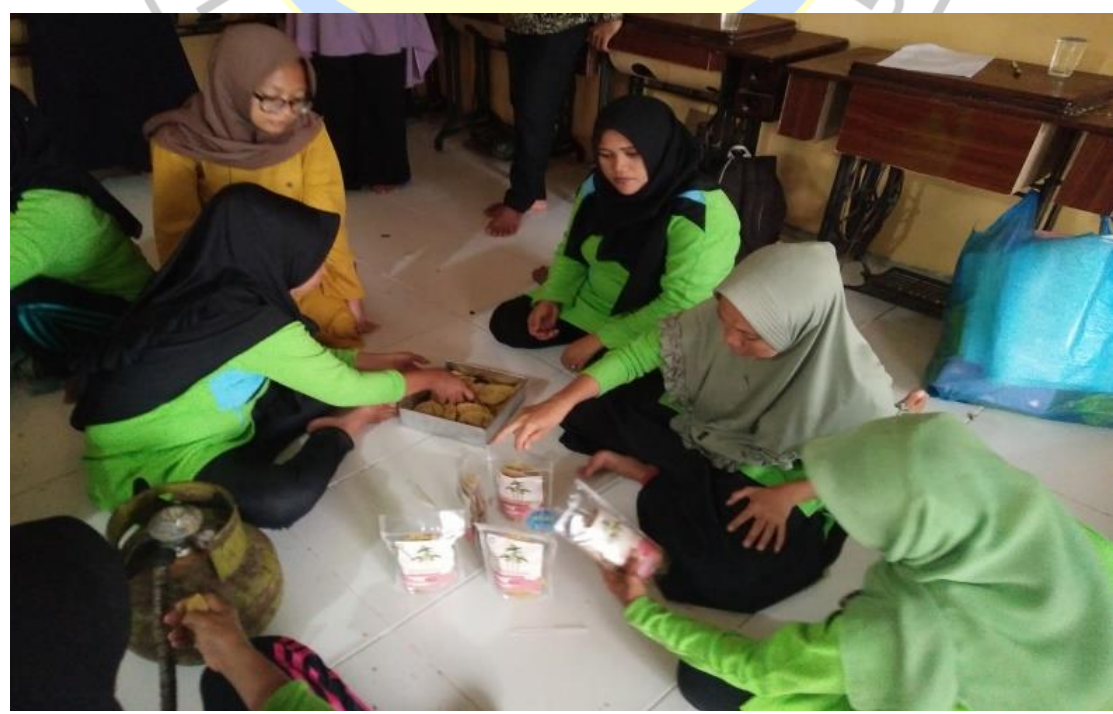

Gambar 2. Peserta memasukkan produk dalam kemasan 

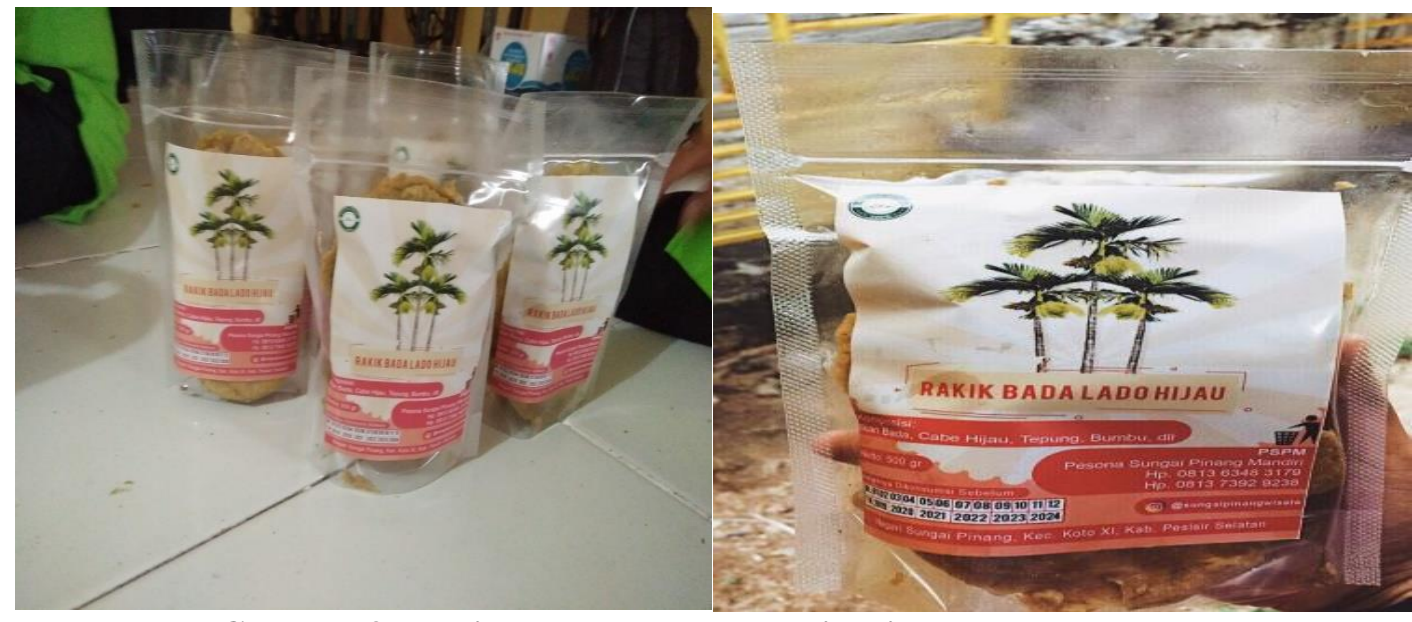

Gambar 3. Rakik bada yang sudah diberi kemasan dan label

Berdasarkan hasil evaluasi terhadap kegiatan maka pengukuran pencapaian target adalah ditunjukkan pada tabel 1 .

\section{Tabel 1. Hasil Evaluasi Kegiatan}

\begin{tabular}{lll}
\hline No & \multicolumn{1}{c}{ Target } & \multicolumn{1}{c}{ Pencapaian } \\
\hline 1. & $\begin{array}{l}\text { Mitra memahami pentingnya pengkemasan } \\
\text { dan pemberian label produk }\end{array}$ & $\begin{array}{l}\text { Mitra telah memahami pentingnya kemasan dan } \\
\text { label produk }\end{array}$ \\
\hline 2. & Produk memiliki kemasan dan label & $\begin{array}{l}\text { Produk Rakik bada Lado Hijau sudah memiliki } \\
\text { kemasan dan label yang baik }\end{array}$ \\
\hline 3. & Peningkatan penjualan 25\% & Jumlah penjualan meningkat 5\% \\
\hline
\end{tabular}

Hasil evaluasi dari tabel 1 dapat diamati bahwa masih ada target yang belum tercapai yaitu peningkatan penjualan $25 \%$. Hal ini dapat disebabkan oleh masih kurangnya promosi dan pemasaran dari produk.

\section{Kesimpulan}

Kesimpulan dari kegiatan pengabdian yang dilakukan adalah sebagai berikut: (1) Mitra sudah memahami pentingnya kemasan dan label produk di kemasan dan memberi informasi kepada konsumen. (2) Mitra sudah memiliki merek (brand) produk yang rencana akan digunakan untuk produk lainnya yang diproduksi oleh PKK Nagari Sungai Pinang. (3) Mitra sudah memiliki kemasan yang baik, lengkap dengan label kemasan yang sesuai dengan peraturan, yang belum mereka miliki adalah BPOM yang harus mereka urus dengan baik. (4) Mitra sudah mendapatkan peningkatan penjualan, namun belum mencapai target.

\section{Daftar Pustaka}

Fajarsari, D. D. (2017). Nilai Pendidikan dalam Kuliner Rendang. Buletin Al-Turas, 23(2), 337-348. https://doi.org/10.15408/bat.v23i2.6315

Fitriani, E., Selinaswati, S., \& Mardhiah, D. (2018). Partisipasi Masyarakat Dalam Pembangunan Ekowisata Sungai Pinang. Jurnal Socius: Journal of Sociology Research and Education, 4(2), 8395. doi:10.24036/scs.v4i2.17

Fitriani, E. dkk. (2017). Partisipasi Masyarakat dalam Pembangunan Ekowisata Sungai Pinang. http://repository.unp.ac.id/13454/1/laporan akhir penelitian pemula erda fitriani.pdf 
Hantoro, M. R., \& Soewito, B. M. (2018). Eksplorasi Desain Kemasan Berbahan Bambu sebagai Produk Oleh-oleh Premium dengan Studi Kasus Produk Makanan UKM Purnama Jati Jember. Jurnal Sains Dan Seni ITS, 7(1). https://doi.org/10.12962/j23373520.v7i1.30041

Maryama, S., Yandri, P., Imal, \& Istima. (2018). Pembuatan Packaging Dalam Upaya. SEMBADHA 2018 Seminar Hasil Pengabdian Kepada Masyarakat, vol 1(1), 156-159. http://jurnal.stan.ac.id/index.php/sembadha/article/download/365/255

Pratiwi, R. (2019). Pencantuman Komposisi Bahan pada label sebagai Hak Hukum di Kota Pekanbaru. Gagasan Hukum, 1(1), 63-87.

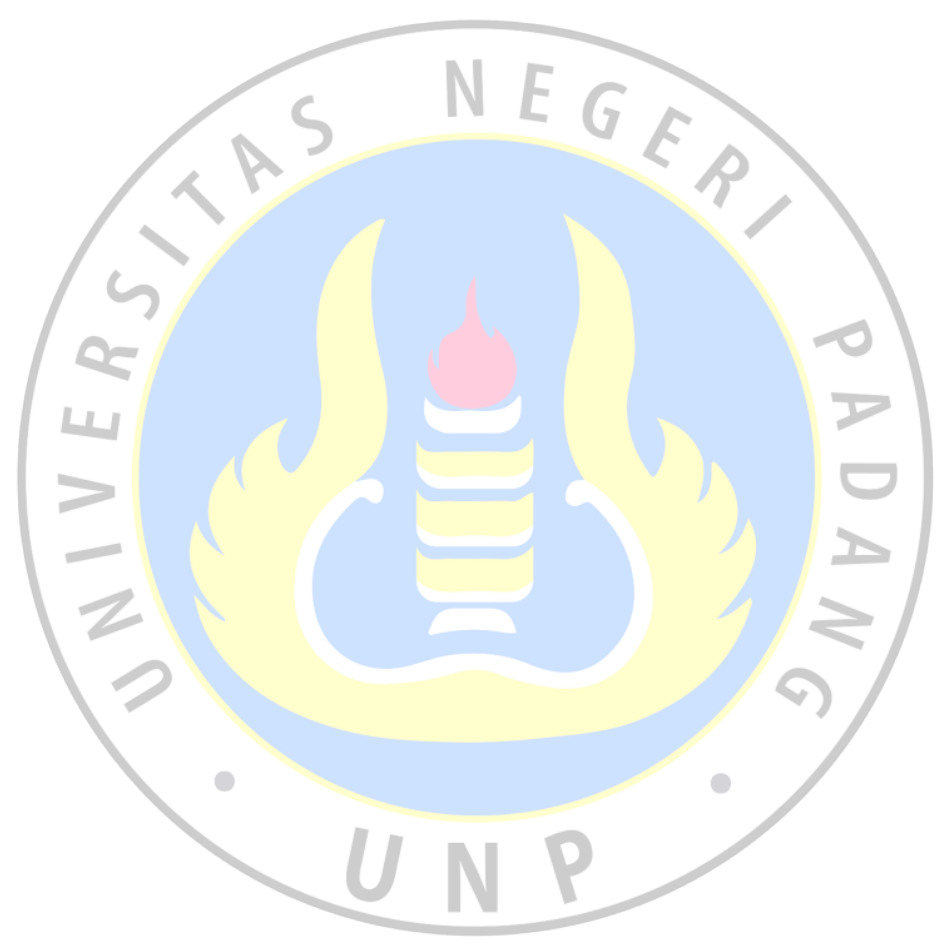

